\title{
Contrast-enhanced ultrasound and detection of carotid plaque neovascularization
}

Figure Contrast-enhanced ultrasound
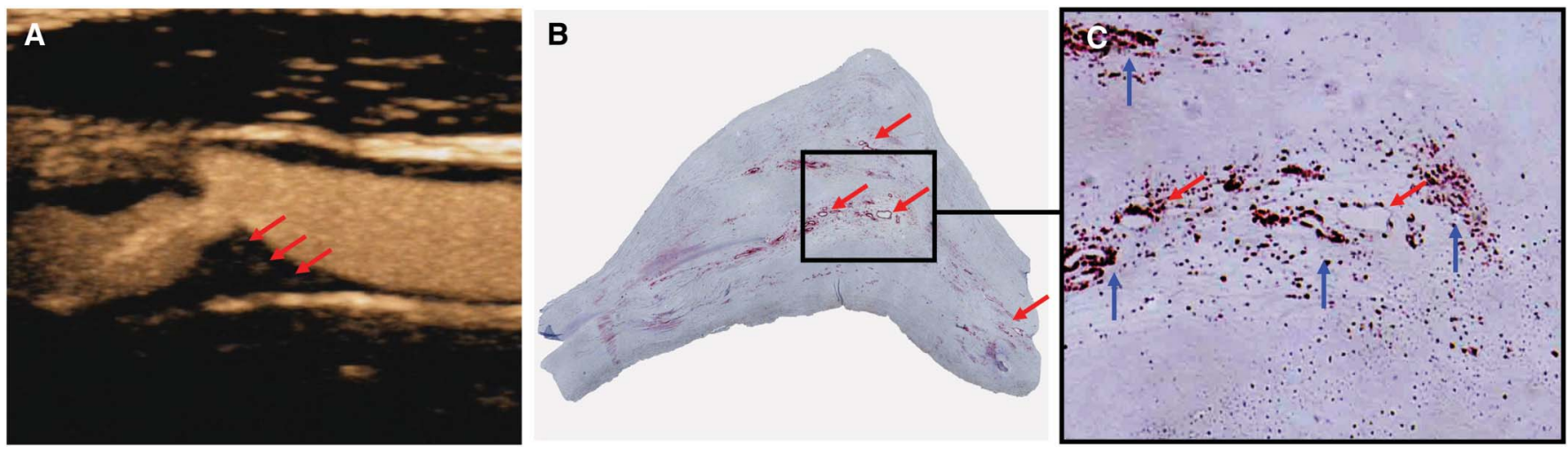

Contrast-enhanced ultrasound (US) reveals plaque neovascularization marked by red arrows (A). Immunohistochemistry of the same carotid plaque after carotid endarterectomy, corresponding to the US findings, shows extensive plaque neovascularization marked by red arrows (B). Neovascularization (red arrows) is associated with dense macrophage infiltration (blue arrows) (C).

A 62-year-old man was admitted after recurrent transient left-sided weakness and sensory loss. Ultrasound (US) examination revealed a $70 \%$ narrowing of the right proximal internal carotid artery (ICA). Contrast-enhanced US suggested plaque neovascularization (figure, A). Carotid endarterectomy of the right ICA was performed. Immunohistochemistry of the specimen showed, corresponding to the US findings, extensive plaque neovascularization associated with dense macrophage infiltration (figure, B, C). Plaque neovascularization is associated with inflammation and plaque progression. ${ }^{1}$ The detection of plaque neovascularization by contrastenhanced US could give further evidence of plaque vulnerability, but further study is needed to determine its value.

Hagen Kunte, MD, Charlotte Schmidt, MS, Lutz Harms, MD, Ralph-Ingo Rückert, MD, PhD, Maria Grigoryev, $M D$, Thomas Fischer, MD, Berlin, Germany

Author contributions: Dr. Kunte, C. Schmidt, Dr. Harms, Dr. Rückert, Dr. Grigoryev, and Dr. Fischer: drafting/revising the manuscript, study concept or design, and analysis or interpretation of data.

The authors report no disclosures relevant to the manuscript. Go to Neurology.org for full disclosures.

Correspondence \& reprint requests to Dr. Kunte: hagen.kunte@charite.de

1. Moreno PR, Purushothaman KR, Sirol M, Levy AP, Fuster V. Neovascularization in human atherosclerosis. Circulation 2006; 113:2245-2252. 


\section{Neurology}

\section{Contrast-enhanced ultrasound and detection of carotid plaque neovascularization}

Hagen Kunte, Charlotte Schmidt, Lutz Harms, et al.

Neurology 2012;79;2081

DOI 10.1212/WNL.0b013e3182749f4c

This information is current as of November 12, 2012

Updated Information \& Services

References

Subspecialty Collections

Permissions \& Licensing

Reprints including high resolution figures, can be found at: http://n.neurology.org/content/79/20/2081.full

This article cites 1 articles, 1 of which you can access for free at: http://n.neurology.org/content/79/20/2081.full\#ref-list-1

This article, along with others on similar topics, appears in the following collection(s):

All Cerebrovascular disease/Stroke

http://n.neurology.org/cgi/collection/all_cerebrovascular_disease_strok $\mathrm{e}$

Ultrasound

http://n.neurology.org/cgi/collection/ultrasound

Information about reproducing this article in parts (figures,tables) or in its entirety can be found online at:

http://www.neurology.org/about/about_the_journal\#permissions

Information about ordering reprints can be found online:

http://n.neurology.org/subscribers/advertise

Neurology ${ }^{\circledR}$ is the official journal of the American Academy of Neurology. Published continuously since 1951, it is now a weekly with 48 issues per year. Copyright @ 2012 American Academy of Neurology. All rights reserved. Print ISSN: 0028-3878. Online ISSN: 1526-632X.

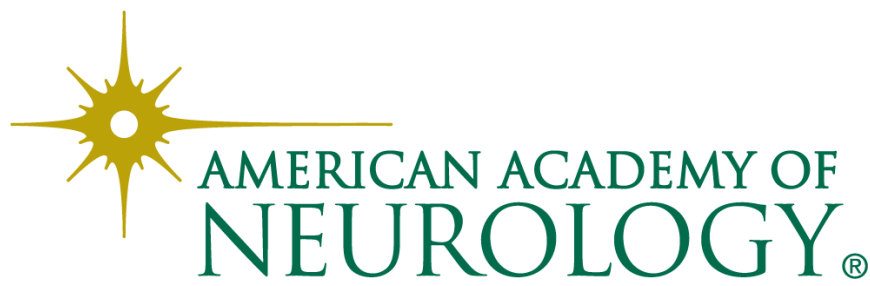

